JoHn FELLOW LARSEN: Helfjende eller halvven. Om Kaj Munk, Ollerup-talen og besættelsen - $\mathrm{i}$ anledning af et flyveblad i den illegale samling

NIELS FOCK: To Verdener mødtes

HARALD ILSøE: Lidt gammel nyt om bibliotekets berømte inkahåndskrift

POUl RASMUSSEN: Pablo Neruda

LARS SCHWANDER: Det tredie øje - omkring Richard Avedons portrætter af Karen Blixen

MARTIN DYRBYE: Albert Helsengreen's samling

MiKael Hansen: Deep Blue: kultur, computer, skak

Hanne Hansen: August. Det kongelige Bibliotek

KRONIK. Oktober-december 1992

PUBLIKATIONER

Udgiver: Det kongelige Bibliotek

Redaktion: Afdelingsbibliotekar Lotte Philipson

I redaktionen: Overbibliotekar Erland Kolding Nielsen

Ekspedition: Det kongelige Bibliotek, Postboks 2149, 1016 København K. Tlf.: 33930111

Oplag: 3.600 - Gratis • Tryk: Det kongelige Bibliotek

Hvor intet andet angives, er eftertryk tilladt med angivelse af kilde og evt. forfatter.

\section{ISSN 0905-5533}

Forsiden: Gadebillede fra St. Laurent du Maroni, Fransk Guyana, ca. 1925. Tegningen er én af ialt 30 kolorerede tegninger fra Fransk Guyana, som findes i Håndskriftafdelingen under signaturen $\mathrm{Ny} \mathrm{kgl.} \mathrm{Samling} \mathrm{2831,} 2^{\circ}$. En registratur over Håndskriftafdelingens 'Americana' er nyligt udgivet; se bagest i Magasin. 


\section{MAGASIN fra Det kongelige Bibliotek}

8. årgang nr. 1 juni 1993 
